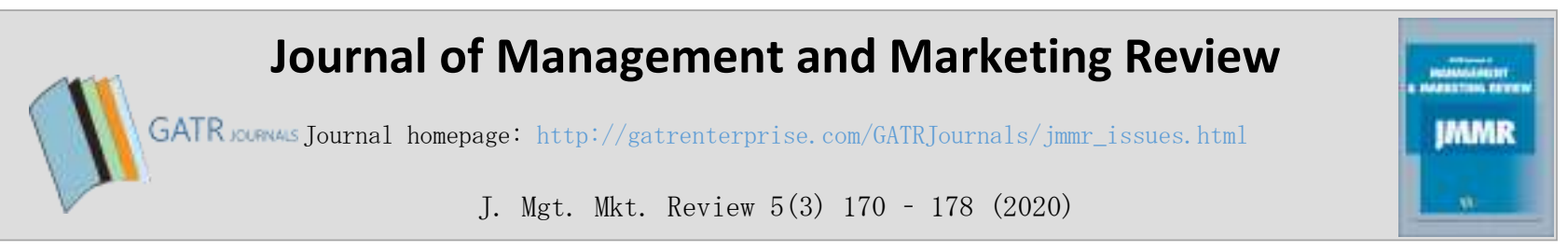

\title{
Do Millennials Believe in Food Vlogger Reviews? A Study of Food Vlogs as a Source of Information
}

\author{
Vita Briliana $^{1 *}$, Wasisto Ruswidiono ${ }^{2}$, Tita Deitiana ${ }^{3}$ \\ ${ }^{1,2,3}$ Trisakti School of Management, Kyai Tapa 20 Grogol, 11440, West Jakarta, Indonesia
}

\begin{abstract}
Objective - Developments in communication technology and social media have enabled business to enter the digital world. This can come in the form of 'vlogs' or 'video blogs' designed by 'vloggers' or 'video bloggers' to present interesting content and concepts. Food vlogs provide detailed information or explanations about the food vloggers have tried and evaluated, in an interesting video format that shows how the seller prepares the food and serves it up, and how it is consumed. The completed video is uploaded to an online channel. Many Indonesian vloggers make use of YouTube to feature their culinary activities. Their vlogs have attracted a huge audience of people looking to enjoy the latest trends in cuisine. To research the determinants of intention to use food vlogger reviews in purchase decisions, the technology acceptance model (TAM) was used to investigate the post-adoption behaviour of Indonesian Millennials in relation to online food vlogger reviews. The existence of links among the perceived benefit of online food vlogger reviews, the usefulness of mobile apps and perceived enjoyment has not been a topic of research to date.

Methodology/Technique - This research uses a purposive sampling technique to select 330 Millennials who have a YouTube application, subscribers to food vlogger channels, and had bought local street food at least once after seeing a food vlogger review. The data of this study employs a path analysis with SPSS 25.0 and Smart-PLS 3.

Findings - The results indicate strong positive effects of the perceived benefit of online food vlogger reviews towards purchase intentions, mobile app usefulness and perceived enjoyment in descending order of effect.

Novelty - Our study has several contributions, including adding insight into the process from before consumers make a purchase; when they find all the information about street food from YouTube; then their interest in buying is generated; and finally, they purchase the food and drinks they have chosen. They can also be reassured that, despite this all happening amidst the Covid-19 pandemic, they need not worry because the seller is adhering to the procedures established by the Government.

Type of Paper: Empirical.

JEL Classification: M31, M37, M9.

Keywords: Perceived Benefit; Mobile App Usefulness; Perceived Enjoyment; Attitude; Intention to Use Food Vlogger Reviews; YouTube; Millennial.

Reference to this paper should be made as follows: Briliana, V; Ruswidiono, W; Deitiana, T. (2020). Do Millennials believe in food vlogger reviews? A study of food vlogs as a source of information, J. Mgt. Mkt. Review, $5(3) 170$ - 178. https://doi.org/10.35609/jmmr.2020.5.3(5)
\end{abstract}

\section{Introduction}

The Covid-19 virus pandemic in Indonesia is having an impact not only on public health, but also on lifestyle, due to the public health policies that have been put in place to help people avoid falling victim to the virus.

\footnotetext{
* Paper Info: Revised: July 22, 2020

Accepted: September 30, 2020

* Corresponding author: Vita Briliana

E-mail: vita@stietrisakti.ac.id

Affiliation: Trisakti School of Management, West Jakarta, Indonesia
} 
The greatest impact has been on people's social lives and the changes they have made in their lifestyles are affecting the economy. Now, with lockdowns and physical distancing policies, people are relying more on digital technology to meet their social and economic needs. Many people feel bored being limited to just doing activities at home, but with a smartphone they can still socialize through access to various social media outlets provided by this technology. These social media outlets can be used as marketing media, interactive media, learning media and entertainment media. The social media outlets that can be used without physical contact include YouTube, Instagram, Facebook, WhatsApp, and TikTok.

The latest We Are Social Report (2020) states that there are 175.4 million internet users in Indonesia. With Indonesia's total population of 272.1 million, that means $64 \%$ access the internet. A study conducted by the Indonesian Internet Service Providers Association (2018) states that $40 \%$ of Indonesia's population are Millennials, born between 1981 and 1996, and aged 24 to 39 this year. This generation is the driving force of the digital economy. In Indonesia, YouTube users have reached 88\% of Internet users (We Are Social, 2020), making YouTube the most popular social media platform in Indonesia (Katadata, 2020). The advantage of YouTube is that fellow users can contribute videos and can connect to Instagram through the YouTube app.

Street food in Indonesia is growing rapidly as it attracts more curious customers. This popularity is because it represents Indonesian people's love for and interest in the cultures from which the different kinds of cuisine originate. The many types of Indonesian food are representative of the diversity of cultures that make Indonesia a country that is rich in authentic and delicious food. If managed properly, street food has tourism potential, that will benefit the economy, because local street food is a part of Indonesian cultural life. A previous study by Zainal et. al. (2017) found that attitudes towards electronic word-of-mouth (eWOM) influence travelers' intentions and their decisions to follow the advice of experienced professionals in the tourism industry. Besides street food, the majority of Millennials spend the greatest portion of their income on buying food from restaurants (Nyheim et. al., 2015). Furthermore, according to Briliana (2018), it has been revealed that their main motivation for visiting restaurants is that they are looking for fine dining experiences. So it is imperative that restauranteurs understand their customers' shopping expectations and behavior.

Several previous studies have discussed eWOM (Briliana et. al., 2019) in the form of consumer reviews posted online. Sharing information or personal opinions in posts on social media has become a very powerful method of communication as a basis for other consumers to consider when deciding on product purchases (Jalilvand \& Samiei, 2012; Briliana et. al., 2015; Mummumi et. al., 2019), hotel mobile apps (Seonjeong Lee, 2018), cosmetic products on social media platforms (Liu et. al., 2019), and Millennial traveling without a travel agent's assistance (Briliana et. al., 2019). eWOM is an opinion leader, i.e. people have the power to influence others' decisions. In this study a food vlogger is an opinion leader, and the decision in question is the purchase of local street food. The information published by food vloggers can create confidence in the minds of consumers that what will be delivered is true. This impression is supported by the displays of images or videos of food and drink. In the current pandemic situation, the emphasis is also on the hygienic procedures mandated by the Government such as washing hands, wearing masks, checking temperatures and keeping appropriate physical distance.

This paper aims to study the process from before consumers make a purchase, when they find all the information about street food from YouTube, then their interest in buying is generated, and finally they purchase the food and drinks they have chosen. They can also be reassured that, despite this all happening amidst the Covid-19 pandemic, they need not worry because the seller is adhering to the procedures established by the Government. The theories of perceived benefit, usefulness, and enjoyment, and attitude can be integrated into one framework to predict the intention to use food vlogger reviews on mobile applications, because each theory has already been used as a predictor of behavior. However, the significance of vlogs as a marketing tool and an understanding of the marketing results related to vlogging needs further investigation. 


\section{Literature Review}

The cooperation model, the best-known attribution theory, was developed by Kelley (1967). The attribution process relates beliefs to a process of perception, and that attributes can be applied to people (dispositional) or the environment (situational). As an example, Millennials like watching certain YouTube shows, so there are 2 possibilities. The first possibility is that they can state that the program is indeed fun (external attribution) and the second, they can state that they are indeed in a happy state, so they like the YouTube program (internal attribution).

\subsection{Mobile App Usefulness}

Recently, research by Briliana et. al. (2019) found that mobile app usefulness means that anytime and anywhere, it is an easy tool to find relevant information, for example, finding a restaurant location, menu variations, operating hours and prices, in addition to information for booking hotel rooms, and learning about destinations when Millennials are planning a trip. Ho (2012) found that when individuals experience new or enjoyable and useful experiences while using mobile apps, they are motivated to use them again. For example, a mobile application showing YouTube and Instagram channels, with reviews from food vloggers in the description section, is often written as a restaurant or a street food location link to the Google map application to make it easier for people to find other locations as well. The site will also be supported by links that connect to food delivery services. This further facilitates and provides experience in using technology to find information additional to the original search. Millennials usually do not automatically use branded application activities because they are in Google Play, meaning they only engage with an application when they really want to use it (Bellman et. al., 2011; Briliana et. al., 2019). For instance, most Millennials download mobile applications such as Google Maps, transportation, hotel reservation applications and ticket purchase applications when they plan to travel independently.

\subsection{Perceived Enjoyment}

Perceived enjoyment refers to when consumers feel happy when they access certain sites. The more consumers experience pleasure when shopping online on a particular site, the more likely they are to make purchases on that site. It has become Millennials' habit to focus on social media (e.g. YouTube and Instagram) just for fun or seeking support for their decisions through eWOM (Briliana et. al., 2019). Millennials like to see and discuss interesting stories that emerge from the comments. They think watching an exchange of information is funny and it confirms their identity as experienced consumers who love to share positive experiences with others who have the same interests; that is, they enjoy eating. A previous study by Zainal et. al. (2017) found that attitudes toward eWOM influenced travelers' intentions to follow the advice of experienced professionals in the tourism industry. Viewers with stronger motives (conceptualized as perceived enjoyment felt by watching vlogger presentations) tend to pay more attention to videos with the same content, which makes them feel connected with the vloggers and other viewers (Liu et. al., 2019).

\subsection{Perceived Benefit of Online Food Vlogger Reviews}

Research recently conducted by Mumumi et. al., (2019) states that consumers feel the need to seek information from social media that discusses a product and, as much as possible, they consult with online product reviews before making a purchase decision, in order to reduce worry about product quality. Caruana and Ewing (2010) found that online businesses generally offer low search costs, so online businesses also need to offer competitive prices. The digital impact allows consumers to easily consider prices and compare the benefits offered. The availability of online information displayed on YouTube, such as food vlogger reviews or recommendations, makes them easily accessible. This enables potential customers to use the 
internet to compare the features and prices of the products and services offered before making a purchase decision. Larivière et. al. (2013) reveal that mobile applications can be instrumental, experiential, related to identity and social.

\subsection{Attitude Toward Online Food Vlogger Reviews}

A tendency is emerging for consumers to be more dependent on and pay greater respect to the opinions expressed in online product reviews, in comparison to other sources of information (e.g. friends or relatives). This is because online reviewers are considered to be more experienced and experts in this field, shaping consumer attitudes towards certain media (Mumumi et. al., 2019). Basically, tourists seek advice and recommendations from online social networks when planning their trip because the opinions of more trusted friends are shared through social media (Oliveira et. al., 2020). Past empirical studies have also found discussions on social media among consumers who have the same interests in an activity, reading content, sharing knowledge and experiences in considering purchasing decisions. They place more trust in the reviews (e.g. photos and videos) of people who have tried a product and evaluated it (Munar \& Jacobsen, 2014; Briliana, 2018).

\subsection{Intention to Use Food Vlogger Reviews for Purchase Decisions}

Research by Kusumasondjaja and Tjiptono (2019) found there are circumstances that encourage consumers to seek information on Instagram; they understand it and are ultimately interested in buying the products advertised on that app. When consumers see YouTube shows, they look for information about vlogger reviews of the food and drinks offered as street food including menu variations and recommendations, prices, how to consume the food, hours of operation, and the atmosphere. Food vloggers start by showing how the food is cooked and served, accompanied by spontaneous interviews between the food vloggers and the sellers or chefs. In the phase where the food vlogger is actually eating the food, sharing the experience of consuming vicariously becomes most important for inspiring purchasing decisions. If the social media sites present interesting content and positive messages, viewers feel a sense of connection to and trust in the people who are posting the messages (Yuan et. al., 2016; Liu et. al., 2018), thereby increasing the intimacy felt by the audience with the vloggers. This can lead to some viewers developing increased attachment or even dependence on the vlogs, so that they become fans who watch the postings regularly and even subscribe.

\section{Research Methodology}

The purpose of this study is to determine the factors that influence the intention to use food vlogger reviews by Millennials. The sampling technique used was a non-probability sampling technique which is judgment sampling. The data analysis method used was SEM (Structural Equation Model) based on PLS (Partial Least Square). Partial least square (PLS) regression analysis was selected because all paths can be assessed simultaneously for model prediction (Jr, Hult, Ringle, \& Sarstedt, 2016). The SmartPLS 3.0 software package was used to assess the model in 2 stages, fulfilling the criteria suggested by Anderson and Gerbing (1988) and Briliana and Mursito (2017).

Mobile app usefulness, perceived enjoyment and perceived benefit, were proposed as antecedents of attitude toward online food vlogger reviews in the first stage of the model, covering H1, H2 and H3. The second stage of the model was used to study how attitude influences online food vlogger reviews in the proposed Intention to use them for purchase decisions, covering H4. The figure below illustrates the conceptual framework on which this research is based. 


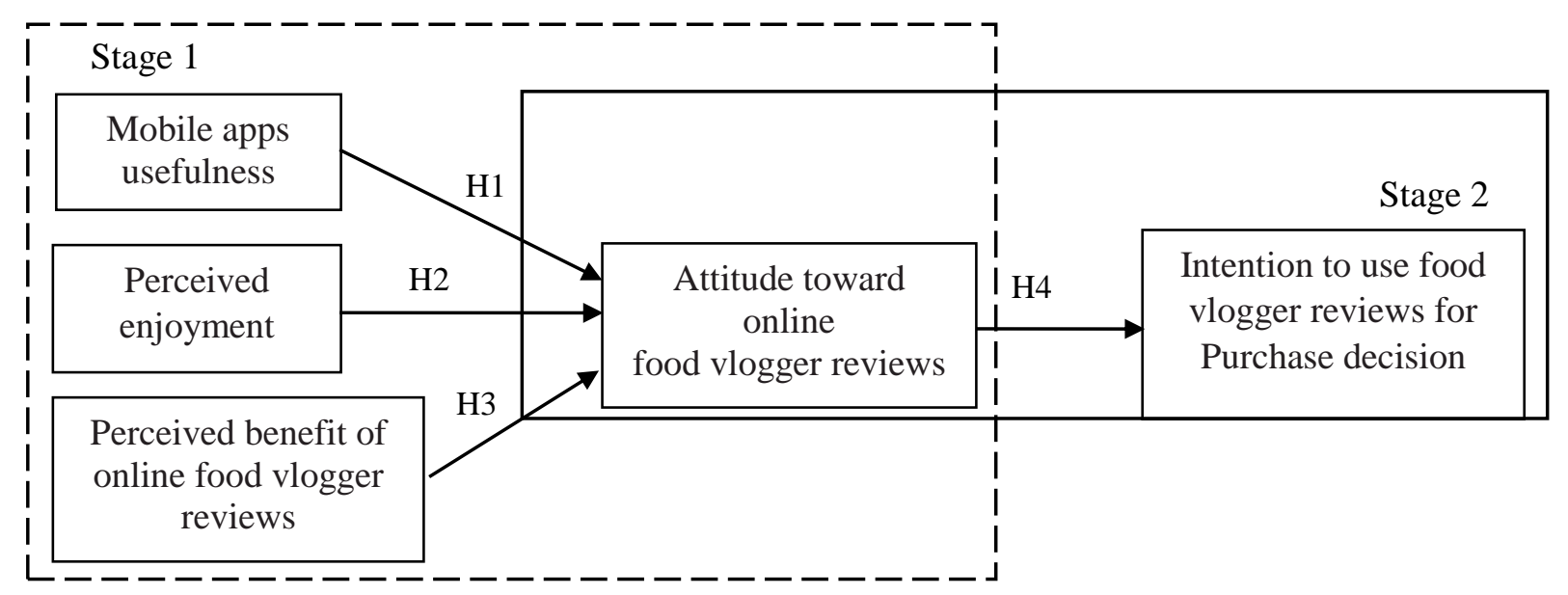

Figure 1. Conceptual Framework

H1. The greater the mobile app usefulness, the stronger the attitude towards online food vlogger reviews.

$\mathrm{H} 2$. The greater the perceived enjoyment, the stronger the attitude towards online food vlogger reviews.

H3. The greater the perceived benefit, the stronger the attitude towards online food vlogger reviews.

H4. The greater the attitude toward online food vlogger reviews, the stronger the intention to use food vlogger reviews for purchase decisions.

Primary research was conducted through online surveys, which was appropriate considering the vlogging context. Filtering questions were asked to ascertain that the participating Millennials had previously seen food vlogs and met other pre-set criteria. These criteria were: Millennials who have a YouTube application, subscribers to food vlogger channels, and had bought local street food at least once after seeing a food vlogger review. The participants viewed a selected video that reviewed local street food on YouTube. After watching the video, they filled out the questionnaire. A total of 330 questionnaires were completed.

\section{Results}

The sample profile results indicate that the highest percentage of respondents $(68.8 \%)$ are male, aged 21 to 24 years old, with approximately $48.5 \%$ being students. Most $(89.4 \%)$ admitted that they routinely viewed YouTube food vlogs and also posted comments about their experiences on social media, in particular on YouTube and Instagram (95.5\%).

Table 1. Measurement Model Indicators

\begin{tabular}{|c|c|c|c|c|}
\hline \multicolumn{2}{|c|}{} & Loading & CR & AVE \\
\hline ATO1 & $\begin{array}{c}\text { In making the decision to buy the food and beverages, food } \\
\text { vlogger reviews are very helpful. }\end{array}$ & 0.750 & 0.897 & 0.637 \\
\hline ATO2 & $\begin{array}{c}\text { I am confident in buying food and drinks because of online food } \\
\text { vlogger reviews }\end{array}$ & 0.833 & & \\
\hline ATO3 & Online food vlogger reviews are informative. & 0.849 & & \\
\hline ATO4 & $\begin{array}{c}\text { To discover good things about food and beverages come from } \\
\text { Online food vlogger reviews is a great way. }\end{array}$ & 0.751 & \\
\hline ATO5 & $\begin{array}{c}\text { To discover bad things about food and beverages come from } \\
\text { Online food vlogger reviews is a great way. }\end{array}$ & 0.801 & \\
\hline Perceived enjoyment - adapted from Briliana \& Prasetio. (2018); Liu et. al. (2019) & 0.750 & 0.912 & 0.564 \\
\hline PEY1 & I watch food vlogs to fill my free time. & & \\
\hline
\end{tabular}




\begin{tabular}{|c|c|c|c|c|}
\hline PEY2 & I watch food vlogs because they are entertaining. & 0.747 & & \\
\hline PEY3 & When I'm bored, I often spend time watching food vlogs & 0.773 & & \\
\hline PEY4 & I watch vlogs because they are relaxing & 0.761 & & \\
\hline PEY5 & I watch food vlogs because they are cool to watch. & 0.774 & & \\
\hline PEY6 & I am excited when I watch food vlogs. & 0.755 & & \\
\hline PEY7 & I have fun when I watch food vlogs. & 0.749 & & \\
\hline PEY8 & I watch food vlogs in order to communicate with others. & 0.695 & & \\
\hline \multicolumn{4}{|c|}{ Mobile app usefulness (MAU) - adapted from Briliana et. al., ( 2016) } & \\
\hline MAU1 & Using the mobile app can complete tasks faster & 0.790 & 0.869 & 0.689 \\
\hline MAU2 & Using the mobile app can complete tasks easier & 0.847 & & \\
\hline MAU3 & Overall, the ___ mobile app is useful. & 0.853 & & \\
\hline \multicolumn{5}{|c|}{ Perceived benefit of online food vlogger reviews - adapted from Mumuni et. al., (2019) } \\
\hline PBO1 & $\begin{array}{l}\text { I can find information about food and beverage products that I } \\
\text { will buy }\end{array}$ & 0.759 & 0.885 & 0.608 \\
\hline PBO2 & I got positive information about the food and drink that I will buy & 0.819 & & \\
\hline PBO3 & I got negative information about the food and drink that I will buy & 0.853 & & \\
\hline PBO4 & To avoid a bad purchase & 0.829 & & \\
\hline PBO5 & To make sure I make a good purchase choice & 0.617 & & \\
\hline \multicolumn{5}{|c|}{$\begin{array}{l}\text { Intention to use food vlogger reviews for purchase decision - adapted from Kusumasondjaja and } \\
\text { Tjiptono (2019) }\end{array}$} \\
\hline ITS1 & $\begin{array}{l}\text { After viewing the food vlogger review, I became interested in } \\
\text { making a purchase. }\end{array}$ & 0.836 & 0.876 & 0.587 \\
\hline ITS2 & $\begin{array}{l}\text { After viewing the food vlogger review, I am willing to purchase } \\
\text { the food and beverages being advertised. }\end{array}$ & 0.747 & & \\
\hline ITS3 & $\begin{array}{l}\text { After viewing the food vlogger review, I would consider } \\
\text { purchasing the advertised food and beverages. }\end{array}$ & 0.759 & & \\
\hline ITS4 & $\begin{array}{l}\text { After viewing the food vlogger review, I will probably purchase } \\
\text { the food and beverages being advertised. }\end{array}$ & 0.763 & & \\
\hline ITS5 & $\begin{array}{l}\text { After viewing the food vlogger review, it is very likely that I will } \\
\text { buy the food and beverages being advertised. }\end{array}$ & 0.720 & & \\
\hline
\end{tabular}

Table 2. PLS Results of Discriminant Validity Measures

\begin{tabular}{|c|c|c|c|c|c|}
\hline & ATO & ITS & MAU & PBO & PEY \\
\hline ATO & 0.798 & & & & \\
\hline ITS & 0.794 & 0.766 & & & \\
\hline MAU & 0.771 & 0.768 & 0.830 & & \\
\hline PBO & 0.911 & 0.857 & 0.773 & 0.780 & \\
\hline PEY & 0.821 & 0.851 & 0.773 & 0.834 & 0.751 \\
\hline
\end{tabular}

Table 3. Hypotheses Testing Results

\begin{tabular}{|l|ccl|c|c|c|c|c|}
\hline & \multicolumn{3}{|c}{ Path } & Beta & Standard error & t value & P value & Supported \\
\hline H1 & ATO & $\rightarrow$ & ITS & 0,794 & 0,023 & 35,023 & 0,000 & Yes \\
\hline H2 & MAU & $\rightarrow$ & ATO & 0,118 & 0,045 & 2,626 & 0,009 & Yes \\
\hline H3 & PBO & $\rightarrow$ & ATO & 0,693 & 0,054 & 12,773 & 0,000 & Yes \\
\hline H4 & PEY & $\rightarrow$ & ATO & 0,151 & 0,053 & 2,855 & 0,004 & Yes \\
\hline
\end{tabular}




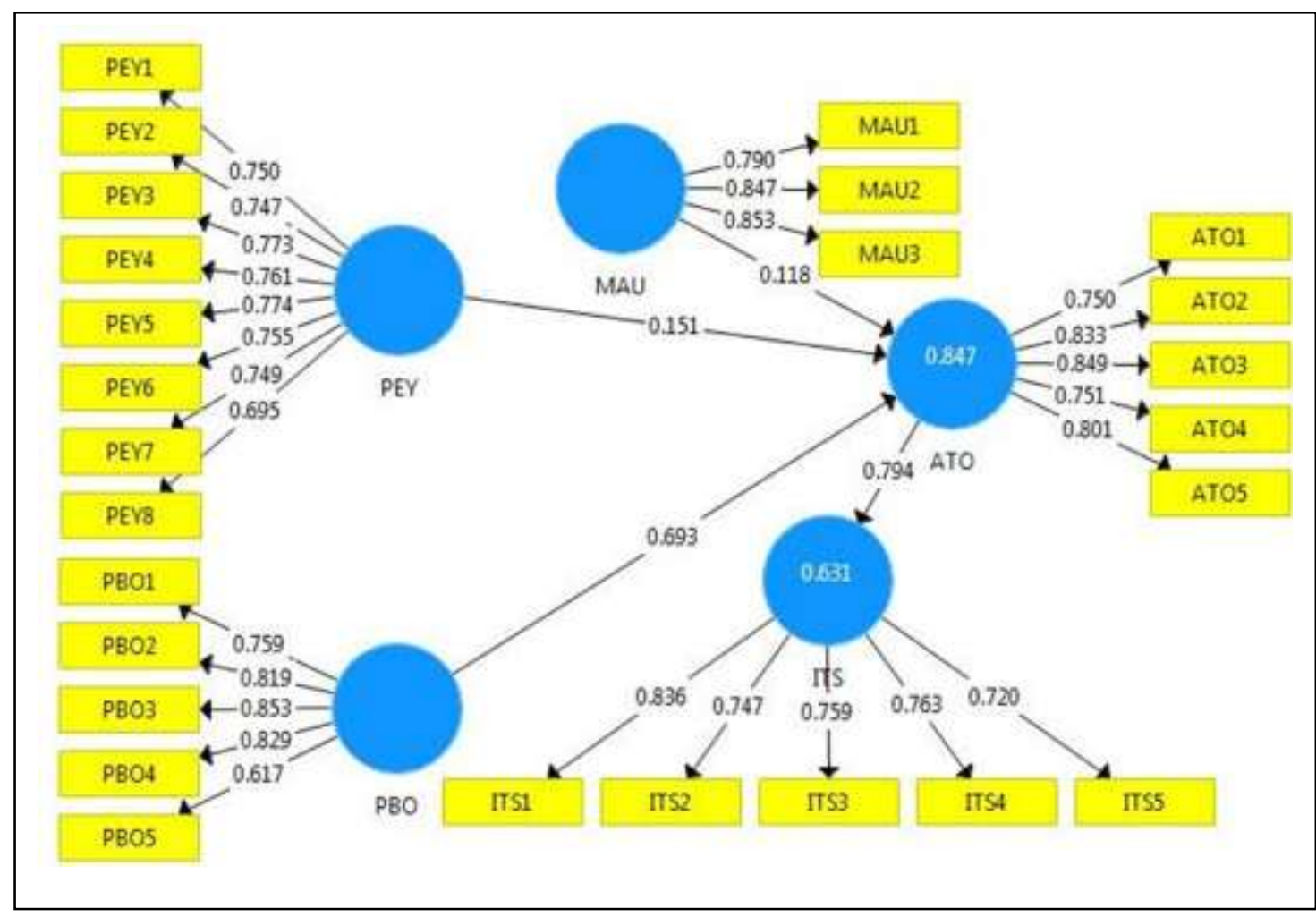

Figure 2. Conceptual Framework

\section{Discussion}

Overall, consumer attitudes and purchase intentions arise from the influence of expert endorsers (Limbu et. al., 2012). The impact of online food vlogger reviews (e.g. YouTube and Instagram) on the food and beverage industry can be seen from 2 dimensions, namely before and after consumption. Before Millennials try a new culinary experience, they look for information and recommendations about food that suits their tastes (Briliana et. al., 2019). After consumption, they evaluate the experience and how well it measured up to the review/s that inspired them to try the food. They in turn become food critics, sharing their culinary experience in the same social media to confirm or dispute the opinions of the food vloggers or their friends.

People have different preferences so they look for the experience of consuming authentic flavors to satisfy their tastes. Images of restaurant facilities or street food environments that give the impression of an atmosphere that is unique, attractive and comfortable are captured and posted on Instagram or YouTube channels. Comments can also be read and responded to on these channels.

Vlogging is attracting an increasingly large population of viewers (Freeman \& Chapman, 2007; Ferchaud et. al., 2018). Marketers must understand the characteristics of vloggers and viewers so they can predict changes in lifestyle and tastes, in order to potentially create value and memorable experiences for consumers.

The increasing number of Millennials who are social media and YouTube users, and who are subscribers to food vlog accounts, can influence consumer buying interest in the food products offered. Millennials are the keenest consumers of experiences compared to previous generations (Briliana, 2019). For this generation, brand is not the main factor when choosing a product or service, but the rating, recommendations and perceived benefits offered are a greater influence. 


\section{Conclusion}

Social media has changed the space for communication, expression and self-actualization. Many benefits are obtained from using social media, such as friendship networks, branding, and providing business potential as an endorser. The ways information is conveyed have changed from much simpler media to social media, which have advantages in that they can be accessed easily, and have seemingly unlimited resources in the sense that everyone can be a resource. The rapid development of social media is connecting consumers who have the same interests as one another in online communities. As a result, marketers, in this case restaurant entrepreneurs could lose control of the brand (Wu \& Lin, 2017). Technological developments provide business opportunities in digital media and food vloggers are taking advantage of these opportunities to present interesting content. YouTube provides a useful digital platform that enables Indonesian vloggers to present their culinary interests and activities in attractive and informative ways. It is therefore understandable that the public is turning to them as a reference for discovering delicious and trendy cuisine. To succeed, start-up and application managers must develop business strategies by understanding the characteristics of the millennial generation of users.

There are limitations to this study that future research could expand on. This research focuses only on examining the appeal of food vlogs, reviewing the experiences of consuming local street food in Indonesia, and discussing how vloggers influence viewers to try new culinary experiences and then act as food reviewers themselves.

\section{Acknowledgements}

We would like to express our deepest gratitude to Ministry of Research, Technology and Higher Education of the Republic of Indonesia for its short-term grant.

\section{References}

Mumuni, A. G., Lancendorfer, K. M., O’Reilly, K. A., \& MacMillan, A. (2019). Antecedents of consumers' reliance on online product reviews. Journal of Research in Interactive Marketing. https://doi.org/10.1108/JRIM-11-2017-0096 Association of Internet Service Companies Indonesia - APJII. (2018). Retrieved June 10, 2020 from https://apjii.or.id/survei2018/download/.

Bellman, S., Potter, R. F., Treleaven-Hassard, S., Robinson, J. A., \& Varan, D. (2011). The effectiveness of branded mobile phone apps. Journal of interactive Marketing, 25(4), 191-200. https://doi.org/10.1016/j.intmar.2011.06.001

Briliana, V., Wahid, N. A., \& Fernando, Y. (2015). The effect of motivation, opportunity, ability and social identity towards customer-to-customer online know-how exchange. Advanced Science Letters, 21(4), 819-822. https://doi.org/10.1166/asl.2015.5887

Briliana, V. (2019). What do Millennials see in Indonesia? An analysis of Generation Y travel intentions through Social Media. African Journal of Hospitality, Tourism and Leisure, GCBSS Special Edition. ISSN: 2223-814X

Briliana, V., Deitiana, T., \& Ruswidiono, W. (2019). How Millennial Travelers Are Forcing Indonesian Tourism To Go Digital. International Journal of Business, Economics and Law, 19(2), 1-7. https://www.ijbel.com/wpcontent/uploads/2019/09/BUS_46.pdf

Briliana, V. (2019). Creating Value through Authenticity and Social eWOM: Evidence from Authentic Traditional Yogyakarta

Cuisines.

https://www.researchgate.net/profile/Vita_Briliana/publication/337915820_Creating_Value_through_Authenticity_and _Social_eWOM_Evidence_from_Authentic_Traditional_Yogyakarta_Cuisines/links/5df2e8ac92851c836478d3b1/Crea ting-Value-through-Authenticity-and-Social-eWOM-Evidence-from-Authentic-Traditional-Yogyakarta-Cuisines.pdf Caruana, A., \& Ewing, M. T. (2010). How corporate reputation, quality, and value influence online loyalty. Journal of Business Research, 63(9-10), 1103-1110. https://doi.org/10.1016/j.jbusres.2009.04.030

Freeman, B., \& Chapman, S. (2007). Is "YouTube" telling or selling you something? Tobacco content on the YouTube video-sharing website. Tobacco control, 16(3), 207-210. http://dx.doi.org/10.1136/tc.2007.020024 
Ferchaud, A., Grzeslo, J., Orme, S., \& LaGroue, J. (2018). Parasocial attributes and YouTube personalities: Exploring content trends across the most subscribed YouTube channels. Computers in Human Behavior, 80, 88-96. https://doi.org/10.1016/j.chb.2017.10.041

Kelley, H. H. (1967). Attribution theory in social psychology. In Nebraska symposium on motivation. University of Nebraska Press. https://psycnet.apa.org/record/1968-13540-001

Jalilvand, M. R., \& Samiei, N. (2012). The effect of electronic word of mouth on brand image and purchase intention. Marketing Intelligence \& Planning. https://doi.org/10.1108/02634501211231946

Hair Jr, J. F., Hult, G. T. M., Ringle, C., \& Sarstedt, M. (2016). A primer on partial least squares structural equation modeling (PLS-SEM). Sage publications. https://us.sagepub.com/en-us/nam/a-primer-on-partial-least-squaresstructural-equation-modeling-pls-sem/book244583

Larivière, B., Joosten, H., Malthouse, E. C., Birgelen, M. V., Aksoy, P., Kunz, W. H., \& Huang, M. H. (2013). Value fusion: The blending of consumer and firm value in the distinct context of mobile technologies and social media. Journal of Service Management, 24(3), 268-293. https://doi.org/10.1108/09564231311326996

Limbu, Y. B., Huhmann, B. A., \& Peterson, R. T. (2012). An examination of humor and endorser effects on consumers' responses to direct-to-consumer advertising. International journal of pharmaceutical and healthcare marketing. https://doi.org/10.1108/17506121211216888

Liu, M. T., Liu, Y., \& Zhang, L. L. (2019). Vlog and brand evaluations: the influence of parasocial interaction. Asia Pacific Journal of Marketing and Logistics. https://doi.org/10.1108/ APJML-01-2018-0021

Munar, A. M., \& Jacobsen, J. K. S. (2014). Motivations for sharing tourism experiences through social media. Tourism management, 43, 46-54. https://doi.org/10.1016/j.tourman.2014.01.012

Jeon, M. M., \& Jeong, M. (2016). Influence of website quality on customer perceived service quality of a lodging website. Journal of Quality Assurance in Hospitality \& Tourism, 17(4), 453-470., https://doi.org/10.1080/1528008X.2015.1127193

Nyheim, P., Xu, S., Zhang, L., \& Mattila, A. S. (2015). Predictors of avoidance towards personalization of restaurant smartphone advertising. Journal of Hospitality and Tourism Technology. https://doi.org/10.1108/JHTT-07-2014-0026

Oliveira, T., Araujo, B., \& Tam, C. (2020). Why do people share their travel experiences on social media?. Tourism Management, 78, 104041. https://doi.org/10.1016/j.tourman.2019.104041

Kim, S., Baek, T. H., Kim, Y. K., \& Yoo, K. (2016). Factors affecting stickiness and word of mouth in mobile applications. Journal of Research in Interactive Marketing. https://doi.org/10.1108/JRIM-06-2015-0046

Lee, S. A. (2018). Enhancing customers' continued mobile app use in the service industry. Journal of Services Marketing., https://doi.org/10.1108/JSM-01-2017-0015

Kusumasondjaja, S., \& Tjiptono, F. (2019). Endorsement and visual complexity in food advertising on Instagram. Internet Research. https://doi.org/10.1108/IntR-11-2017-0459

Wu, T. Y., \& Lin, C. A. (2017). Predicting the effects of eWOM and online brand messaging: Source trust, bandwagon effect and innovation adoption factors. Telematics and Informatics, 34(2), 470-480. https://doi.org/10.1016/j.tele.2016.08.001

Yuan, C. L., Kim, J., \& Kim, S. J. (2016). Parasocial relationship effects on customer equity in the social media context. Journal of Business Research, 69(9), 3795-3803. https://doi.org/10.1016/j.jbusres.2015.12.071

Zainal, N. T. A., Harun, A., \& Lily, J. (2017). Examining the mediating effect of attitude towards electronic words-of mouth (eWOM) on the relation between the trust in eWOM source and intention to follow eWOM among Malaysian travellers. Asia Pacific Management Review, 22(1), 35-44. https://doi.org/10.1016/j.apmrv.2016.10.004 